\title{
UTILIZATION OF ARTIFICIAL INTELLIGENCE TO IMPROVE FLOOD DISASTER MITIGATION
}

\section{PEMANFAATAN KECERDASAN ARTIFISIAL UNTUK MENINGKATKAN MITIGASI BENCANA BANJIR}

\author{
Hammam Riza ${ }^{1}$, Eko Widi Santoso ${ }^{2}$, Iwan G. Tejakusuma ${ }^{2}$, \\ Firman Prawiradisastra ${ }^{2}$, dan Prihartanto ${ }^{2}$ \\ ${ }^{1}$ Badan Pengkajian dan Penerapan Teknologi \\ ${ }^{2}$ Pusat Teknologi Reduksi Risiko Bencana TPSA BPPT \\ JI. M. H. Thamrin No. 8, Jakarta 10340 \\ e-mail: hammam.riza@bppt.go.id
}

\begin{abstract}
Flood disaster is one of predominant disaster event in Indonesia. The frequency and intensity of this disaster tend to increase from year to year as well as the losses caused thereby. To reduce the risks and losses due to flood disasters, innovation in disaster mitigation is needed. Artificial intelligence and machine learning are technological innovations that have been widely applied in various fields of life and can also be used to improve flood disaster mitigation. A literature study conducted in this research shows that the use of artificial intelligence and machine learning has proven to be able, and succeed to fastly and accurately perform flood prediction, flood risk mapping, flood emergency response and, flood damage mapping. ANNs, SVM, SVR, ANFIS, WNN and DTs are popular methods used for flood mitigation in the pre-disaster phase and it is recommended to use a combination or hybrid of these methods. During the flood disaster response phase, the application of artificial intelligence and machine learning are still not much has been done and need to be developed. Examples of the application are the use of big data from social media Twitter and machine learning both supervised learning with Random Forest and unsupervised learning with CNN which have shown good results and have a good prospect to be applied. For the use of artificial intelligence in post-disaster flood phase, are still also rare, because it requires actual data from the field. However, in the future, it will become a promising program for the assessment and application of artificial intelligence in the flood disaster mitigation.
\end{abstract}

Keywords: flood, mitigation, artificial intelligence, supervised learning, unsupervised learning.

\begin{abstract}
Abstrak
Bencana banjir merupakan salah satu kejadian bencana yang mendominasi di Indonesia. Frekuensi dan intensitas bencana ini cenderung meningkat dari tahun ke tahun demikian pula kerugian yang ditimbulkan akibat bencana ini semakin besar. Untuk mengurangi risiko bencana dan kerugian akibat banjir, diperlukan inovasi dalam mitigasi bencana. Kecerdasan artifisial dan pembelajaran mesin merupakan inovasi teknologi yang telah banyak diterapkan di berbagai bidang kehidupan dan dapat juga digunakan untuk meningkatkan mitigasi bencana banjir. Studi literatur yang dilakukan pada penelitian ini menunjukkan bahwa pemanfaatan kecerdasan artifisial dengan pembelajaran mesin terbukti mampu dan berhasil secara cepat dan akurat melakukan prediksi banjir, pemetaan risiko banjir, tanggap darurat banjir maupun pemetaan kerusakan akibat banjir. ANNs, SVM, SVR, ANFIS, WNN dan DTs merupakan metode populer yang digunakan untuk mitigasi banjir dalam tahap prabencana dan direkomendasikan untuk menggunakan gabungan atau hibrid dari metode tersebut. Penerapan untuk tahap tanggap darurat bencana banjir masih belum banyak dilakukan dan masih perlu dikembangkan. Contoh pemanfaatannya adalah penggunaan big data dari media sosial Twitter dan pembelajaran mesin baik supervised learning dengan Random Forest dan unsupervised learning dengan CNN yang telah menunjukkan hasil yang baik dan mempunyai prospek yang bagus untuk diterapkan. Untuk pemanfaatan kecerdasan artifisial dalam tahap pascabencana banjir juga masih belum banyak dilakukan, karena memerlukan data aktual kondisi di lapangan dan ke depan menjadi program penting kaji terap pemanfaatan kecerdasan artifisial.
\end{abstract}

Kata kunci: banjir, mitigasi, kecerdasan artifisial, supervised learning, unsupervised learning. 


\section{PENDAHULUAN}

Penerapan kecerdasan artifisial yang dikenal dengan artificial intelligence atau $A I$, saat ini telah digunakan di berbagai bidang sektor kehidupan kita. Tidak terkecuali pada bidang kebencanaan. Penelitian kecerdasan artifisial pada bidang ini telah berkembang dalam beberapa tahun belakangan ini. Contoh diantaranya adalah penerapan pada bidang bencana banjir, kebakaran hutan dan lahan, gempa, pemantauan gunung api, dan cuaca ekstrim.

Seperti disampaikan dalam ringkasan eksekutif Kongres Teknologi Nasional (KTN) (BPPT, 2018), dalam 15 tahun terakhir pada periode 2003 - 2017, bencana di Indonesia semakin meningkat baik dari jumlah kejadian, maupun skala intensitasnya. Bencana hidrometeorologi (banjir, kekeringan, kebakaran hutan dan lahan, longsor, puting beliung, gelombang pasang) mendominasi peristiwa bencana di Indonesia yaitu sebanyak > 90\% sebagai dampak dari perubahan iklim. Dalam 10 tahun terakhir periode 2011 - 2020 data bencana alam di Indonesia secara jelas menunjukkan peningkatan kejadian bencana (Gambar 1). Berdasarkan data BNPB (gambar 1), kejadian bencana banjir juga menunjukkan tren yang meningkat. Kecenderungan meningkatnya jumlah kejadian dan intensitas bencana, tidak saja terjadi di Indonesia, tetapi juga terjadi dunia.

Upaya pengurangan risiko bencana perlu dilakukan untuk mereduksi bencana yang kian meningkat tersebut. Sendai Framework for Disaster Risk Reduction atau SFDRR 2015-2030, menyepakati perlunya perubahan paradigma pengurangan risiko bencana (PRB) dari prakiraan dan peringatan dini menjadi prakiraan berbasis dampak dan peringatan dini berbasis risiko (impact based forecasting and risk based warning). Selanjutnya, Paris Agreement 2015 yang telah diratifikasi oleh Indonesia pada 31 Oktober 2016 melalui Undang Undang (UU) Nomor 16 Tahun 2016, menggarisbawahi upaya mitigasi, adaptasi, perhitungan loss-and-damage, dan capacity building, termasuk mekanisme pembiayaannya, serta proses monitoring pelaporan setiap negara melalui Nationally Determined Contribution (NDC).

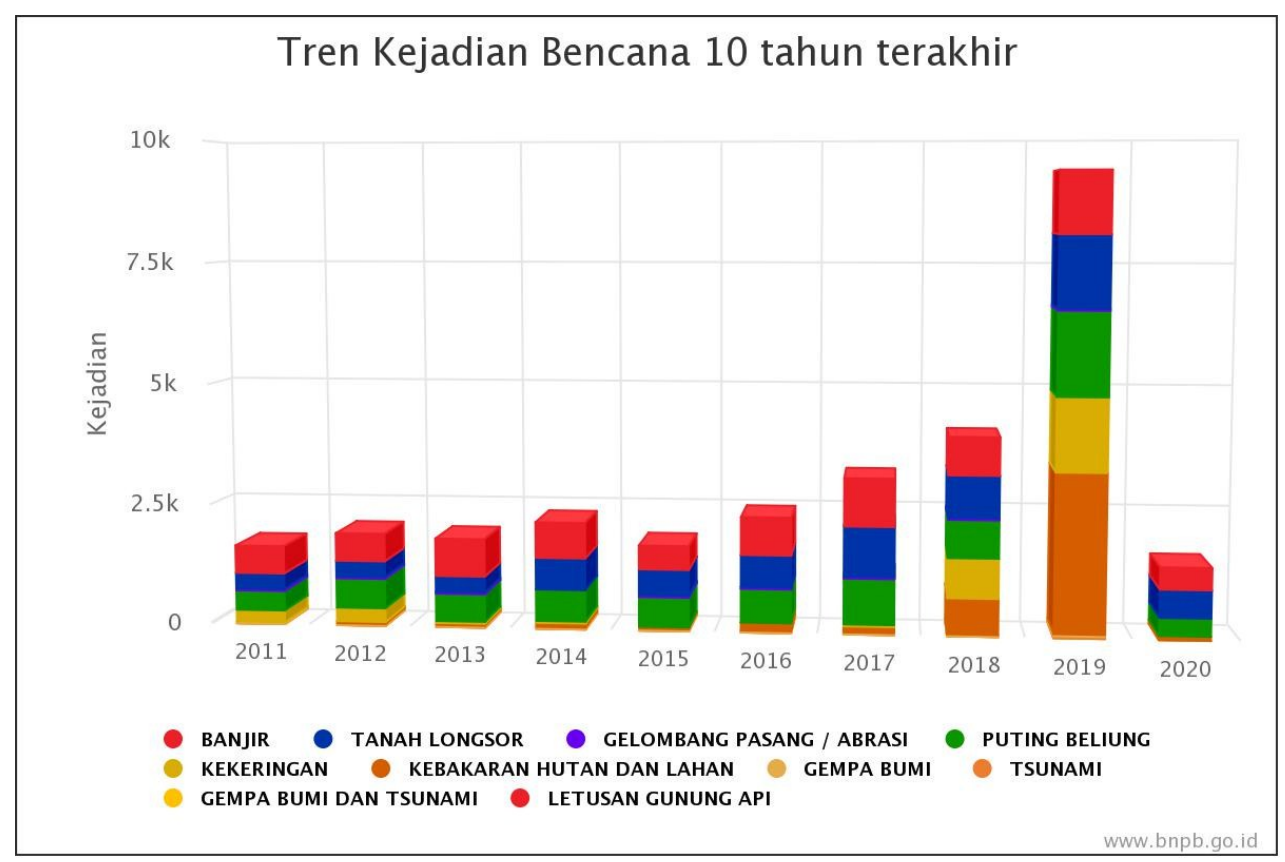

Gambar 1. Tren kejadian bencana alam di Indonesia dalam 10 tahun terakhir periode 2011 - 2020, untuk tahun 2020 waktunya masih berjalan sehingga datanya lebih kecil jumlahnya karena belum lengkap (BNPB, 2020).

Di Indonesia, kerugian materi yang diakibatkan oleh bencana periode $2004-2013$, rata-rata per tahun mencapai 22,8 Triliun (Kompas, 2018). Kondisi ini hanya jika tidak terjadi kondisi yang ekstrim, misalnya El Nino atau tsunami. Kerugian ekonomi akibat El Nino tahun 2015 mencapai 250 Triliun Rupiah atau $0.2 \%$ dari Produk Domestik Bruto (PDB). Besarnya rerata per tahun kerugian ekonomi tersebut, disebabkan antara lain oleh masyarakat 
yang tinggal di daerah bencana atau rentan bencana, tidak tersedianya sistem peringatan dini, semakin tingginya tingkat kerentanan wilayah dan masyarakat tidak memahami gejala bahaya menjadi bencana.

Dalam Undang Undang (UU) Nomor 24 Tahun 2007 tentang penanggulangan bencana (Republik Indonesia, 2007), penyelenggaraan penanggulangan bencana dibagi menjadi 3 (tiga) tahap yaitu prabencana, saat tanggap darurat dan pascabencana. Upaya pengurangan risiko bencana (PRB), seperti halnya diamanahkan oleh SFDRR 2015-2030 maupun UU tersebut sangat memerlukan pengkajian dan penerapan ilmu pengetahuan dan teknologi. Sebagai contohnya adalah dalam memahami, mengamati, memprediksi dan memantau bahaya, kerentanan dan risiko bencana. Selain itu diperlukan pula ilmu pengetahuan dan teknologi dalam melakukan upaya peringatan dini, diseminasi informasi dan pengembangan teknologi baru agar upaya reduksi risiko bencana dapat tercapai secara lebih cepat dan akurat.

Perkembangan ilmu pengetahuan dan teknologi saat ini telah memasuki tahapan Revolusi Industri 4.0 yang berbasis teknologi informasi seperti penggunaan big data, internet of things (IoT), kecerdasan artifisial atau artificial intelligence $(A I)$, crowdsource dan otomatisasi. Secara khusus, penerapan kecerdasan artifisial membuka peluang luas inovasi teknologi untuk mendukung upaya pengurangan risiko bencana melalui sistem cerdas smart risk reduction.

Untuk mengetahui perkembangan terkini diperlukan evaluasi penerapan kecerdasan artifisial dan pembelajaran mesin. Oleh karena itu, dalam tulisan ini akan diuraikan perkembangan penelitian kecerdasan artifisial dan juga pembelajaran mesin serta penerapannya untuk meningkatkan mitigasi bencana banjir.

\section{BAHAN DAN METODE}

\subsection{Bahan}

Dalam penelitian ini, sumberdaya yang digunakan berupa data dan artikel-artikel yang diperoleh dari buku, laporan ataupun jurnal ilmiah terkait studi yang diterbitkan secara nasional maupun internasional. Hasil dari studi literatur terhadap artikel-artikel tersebut digunakan sebagai referensi dalam penulisan makalah ini.

\subsection{Metode}

Penelitian dilakukan dengan metode literature review atau studi literatur khususnya pada publikasi terkini tentang penerapan kecerdasan artifisial atau artificial intelligence (Al) dalam bidang mitigasi bencana banjir. Penelusuran literatur dilakukan dari berbagai sumber seperti buku, lembaran negara, jurnal, website tertentu dari badan dunia atau lainnya khususnya penelusuran melalui internet. Tujuannya adalah didapatkannya gambaran terkini penelitian dan penerapan kecerdasan artifisial dalam upaya mitigasi bencana dan mendeteksi bidang spesifik dari aplikasi kecerdasan artifisial yang dilakukan serta model tertentu yang diaplikasikan. Berdasarkan studi tersebut maka dapat diuraikan perkembangan penerapan terkini yang telah berhasil dilakukan. Selanjutnya, prospek pengembangan dan penerapan kecerdasan artifisial di masa depan serta saran aplikasi kecerdasan artifisial dalam tahapan penanggulangan bencana dapat diberikan.

\section{PEMBAHASAN}

\subsection{Penelitian Kecerdasan Artifisial pada Bencana Banjir}

Banjir merupakan bencana yang paling sering terjadi di wilayah Asia Pasifik dan memiliki dampak yang signifikan pada perekonomian di wilayah tersebut (ESCAP, 2015). Wagenaar et al (2020) menyatakan bahwa metode pembelajaran mesin telah diterapkan dalam penilaian risiko dan dampak banjir khususnya dalam pengembangan langkah-langkah mitigasi, persiapan tanggap darurat dan perencanaan pemulihan banjir. Metode ini memiliki potensi untuk meningkatkan akurasi serta mengurangi waktu penghitungan dan biaya pengembangan model. Pada bencana banjir, penerapan metode kecerdasan artifisial memiliki prospek yang baik dikarenakan model fisik hidrologi membutuhkan data yang besar untuk pemrosesannya sedangkan model kecerdasan artifisial hanya membutuhkan data yang terbatas saja untuk proses prediksinya (Mosavi et al, 2018).

Beberapa penelitian lain terkait aplikasi $A I$ dalam prediksi banjir adalah pemantauan tinggi muka air banjir dengan menggunakan kecerdasan artifisial diantaranya adalah metode Time Variant Inertia Weight Particle Swarm Optimization (TVIWPSO) dan Support Vector Regression (SVR) (Soebroto et al, 2015), metode jaringan syaraf tiruan Radial Basis Function (Sanubari, 2018). Demikian pula pemanfaatan kecerdasan artifisial untuk prediksi curah hujan, debit dan banjir dengan menggunakan Backpropagation Neural Network (BP-NN) dan Support Vector Machine (SVM) (Fitriyaningsih et 
al, 2018). Selain itu penggunaan teknik machine learning atau pembelajaran mesin dapat digunakan untuk meningkatkan ketangguhan dan kesiapsiagaan masyarakat terhadap bencana banjir, dengan mengaplikasikan dan membandingkan kinerja serta akurasi beberapa teknik seperti: Random Forest (RF), Lazy, J48 tree, Artificial Neural Network (ANN), Naïve Bayes (NB), and Logistic Regression (LR). Metode ANN (Artificial Neural Network) digunakan untuk mengembangkan model inundasi regional (Chang et al, 2018). Selain itu pemanfaatan algoritma ANFIS (Adaptive Neuro Fuzzy Inference System) untuk membuat model kerentanan banjir (Bui et al, 2018).

Mosavi et al (2018) juga telah melakukan kajian literatur yang ekstensif serta membuat skema klasifikasi untuk menganalisis literatur yang ada tentang pemodelan pembelajaran mesin untuk prediksi banjir. Lebih dari 6000 artikel telah dikaji dan terdapat 180 artikel yang berpengaruh dan orisinal dimana kemampuan dan akurasi dari sedikitnya dua model pembelajaran mesin telah dibandingkan. Terdapat dua kategori model prediksi yaitu model tunggal dan model hibrid. Hasil yang didapatkan menunjukkan keberhasilan seperti yang ditunjukkan oleh aplikasi metode pembelajaran mesin yang populer yaitu ANNs, SVM, SVR, ANFIS, WNN (Wavelet-based Neural Network) dan DTs (Decision Tree). Mosavi et al (2018) kemudian menunjukkan bahwa kualitas prediksi banjir dapat ditingkatkan dengan beberapa cara yaitu:

a. Melakukan kebaruan dalam hibridisasi, baik melalui integrasi dua atau lebih metode pembelajaran mesin atau integrasi metode pembelajaran mesin dengan cara yang lebih konvensional, dan atau cara komputasi.

b. Penggunaan teknik dekomposisi data untuk tujuan meningkatkan kualitas data set, yang sangat berkontribusi dalam meningkatkan akurasi prediksi.

c. Penggunaan metode ansambel, yang secara dramatis dapat meningkatkan kemampuan model dan mengurangi ketidakpastian dalam melakukan prediksi.

d. Membuat pilihan penambahan algoritma pengoptimal untuk meningkatkan kualitas algoritma pembelajaran mesin, misalnya, dengan memberikan penyesuaian yang lebih baik pada ANNs untuk mencapai arsitektur neuronal yang optimal.

Penggunaan model pembelajaran mesin untuk memprediksi banjir secara spasial merupakan bidang riset yang disarankan untuk kegiatan selanjutnya. Kemajuan terbaru menunjukkan bahwa model pembelajaran mesin untuk analisis banjir secara spasial telah merevolusi bidang prediksi banjir.

\subsection{Penerapan Kecerdasan Artifisial pada Beberapa Tahap Penanggulangan Bencana Banjir}

\subsubsection{Penerapan Kecerdasan Artifisial Pada Tahap Prabencana Banjir}

Penerapan kecerdasan buatan pada fase prabencana yang paling dominan adalah untuk memprediksi kejadian banjir. Metoda pembelajaran mesin berperan penting mempercepat prediksi kejadian banjir terutama untuk jangka pendek sehingga peringatan dini bisa lebih cepat diberikan kepada yang terdampak (Mosavi et al, 2018). Berikut adalah beberapa contoh kasus penerapan kecerdasan artifisial untuk model prediksi bencana banjir.

Aplikasi kecerdasan artifisial melalui pembelajaran mesin dalam upaya pengurangan risiko bencana banjir telah dilakukan oleh para peneliti melalui beberapa metode. Kejadian banjir umumnya diprediksi dengan data curah hujan dan ketinggian muka air sungai.

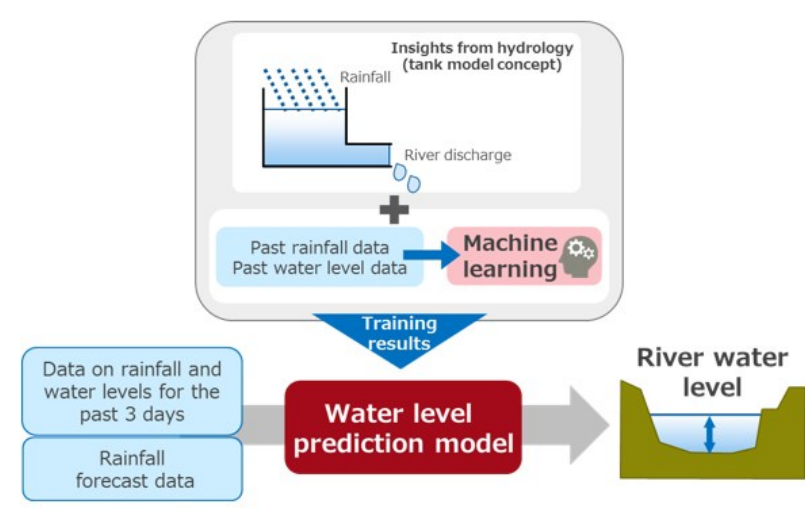

Gambar 2. Diagram ringkas prediksi muka air dengan kecerdasan artifisial (Fujitsu, 2019).

Sebagai contohnya adalah aplikasi kecerdasan artifisial yang dikembangkan Fujitsu (2019), yang dapat memprediksi banjir dengan lebih akurat melalui teknologi dan teknik Fujitsu Human Centric Al Zinrai (Gambar 2). Kecerdasan artifisial yang diterapkan tersebut dapat memprediksi kenaikan muka air sungai secara lebih akurat dari data curah hujan dan muka air sungai (Gambar 3).

Penelitian lainnya menggunakan ANN (Artificial Neural Network) untuk mengembangkan model inundasi regional yaitu the self-organizing map (SOM) dan the recurrent nonlinear autoregressive with exogenous inputs (RNARX) disingkat SOM-RNARX di daerah aliran sungai (DAS) Kemamam, Malaysia (Chang et al, 2018) 
sebagaimana diperilhatkan pada Gambar 4 . Model yang digunakan cukup efektif dan akurat untuk memprediksi kedalaman inundasi pada daerah tersebut dengan waktu yang cukup singkat yaitu beberapa detik saja. Dengan
RMSE keseluruhan $<0,35$ dan $\mathrm{R}^{2}>0,9$ maka model ini dapat dimanfaatkan untuk peringatan dini pada daerah tersebut.

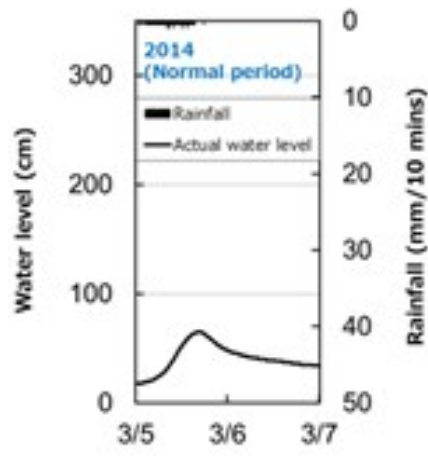

Training data

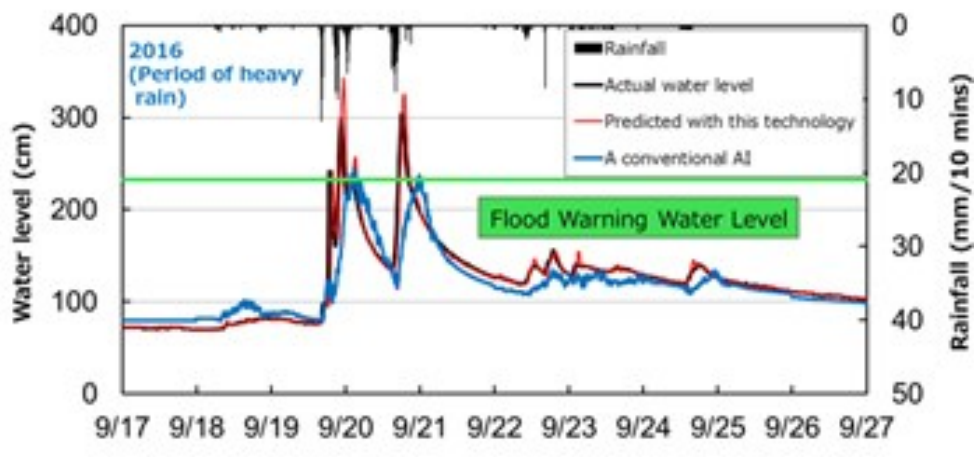

Prediction results

Gambar 3. Kecerdasan artifisial Fujitsu Human Centric Al Zinrai dapat memprediksi kenaikan muka air sungai secara lebih akurat dari data curah hujan dan muka air sungai (Fujitsu, 2019).

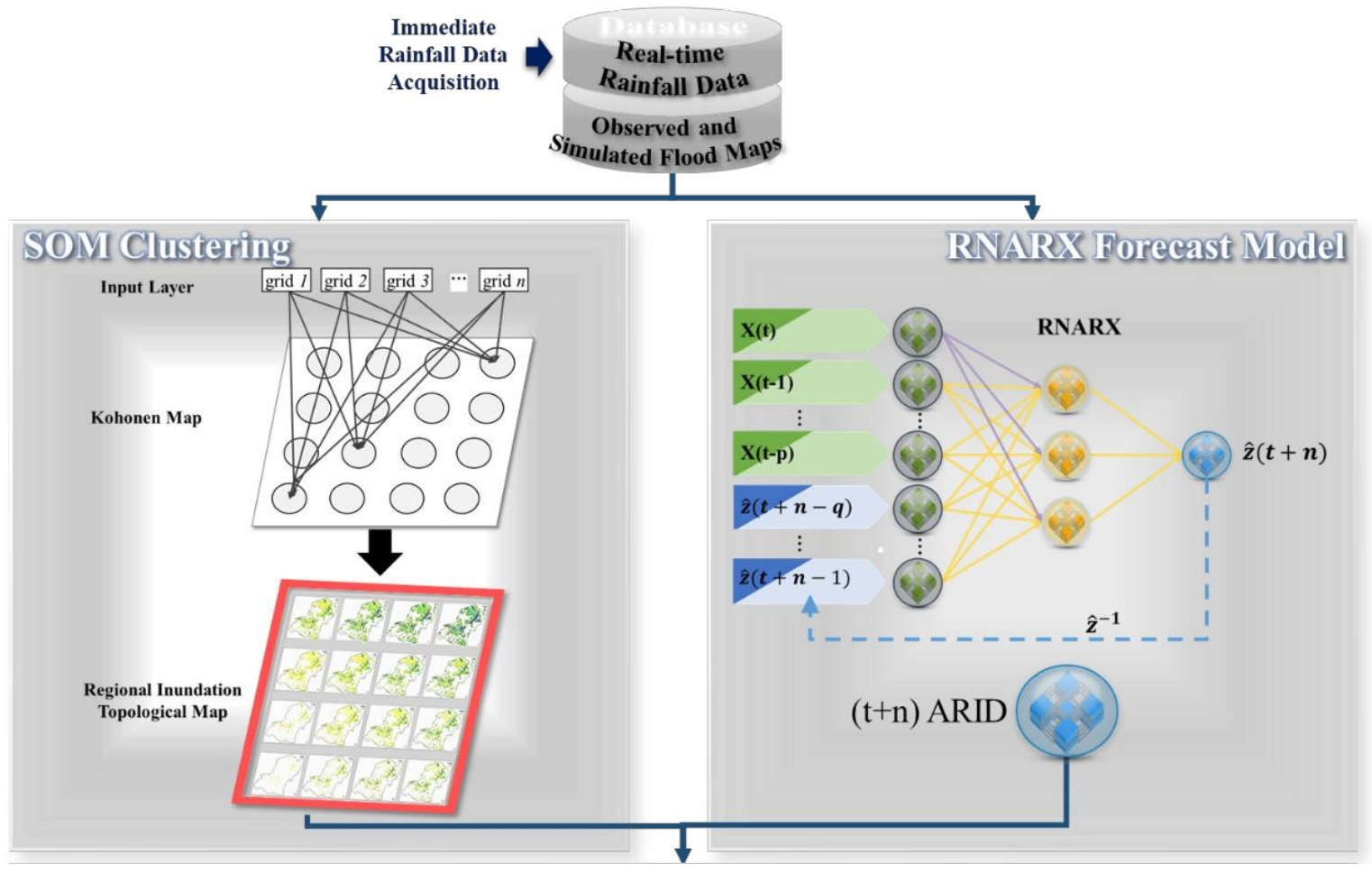




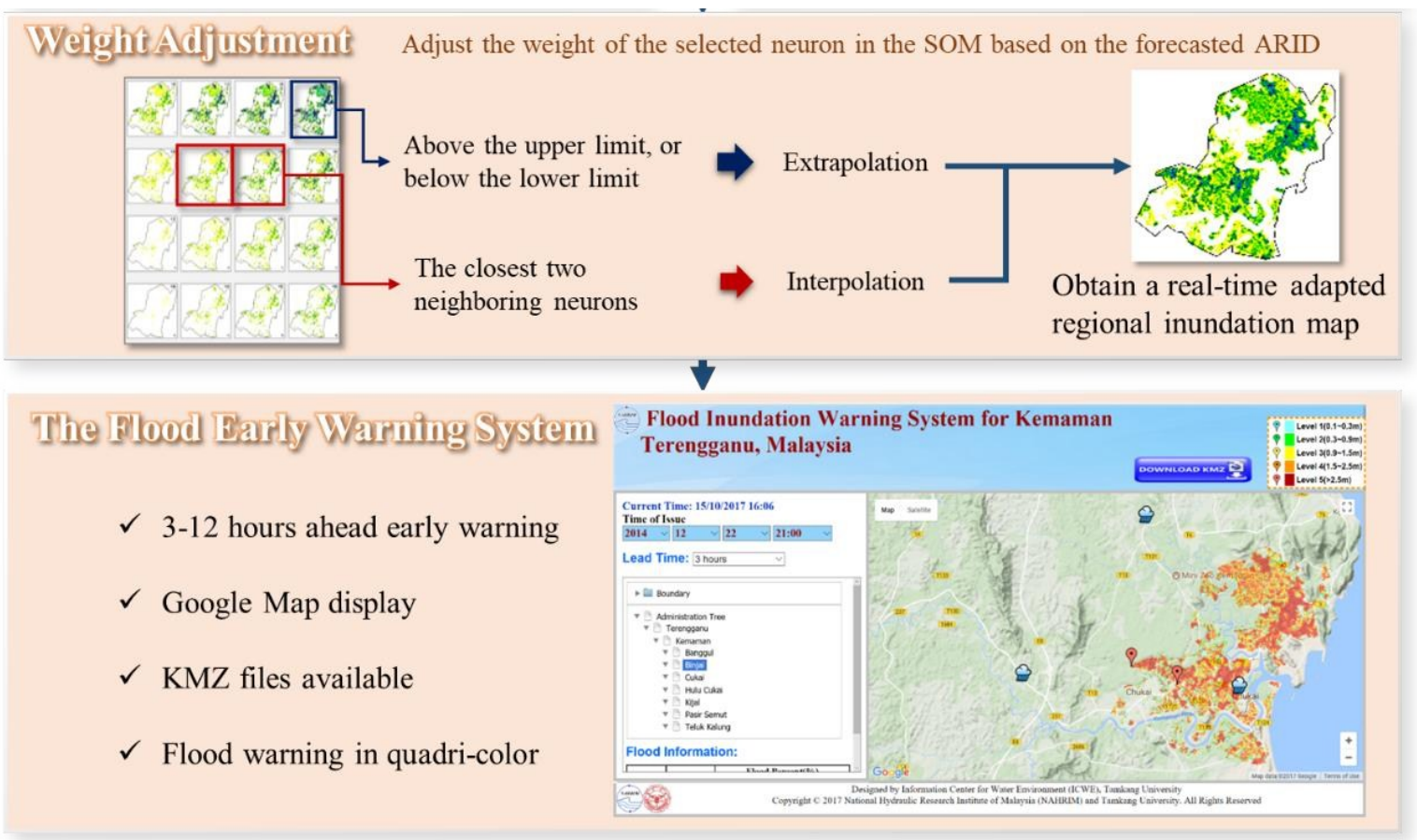

Gambar 4. Metodologi model SOM-RNARX (Chang et al, 2018).

Penelitian lain memanfaatkan algoritma ANFIS untuk membuat model kerentanan banjir di Daerah Aliran Sungai Haraz di Iran (Bui et al, 2018) sebagaimana diperlihatkan pada Gambar 5. Sepuluh faktor pengkondisi banjir kontinu dan kategori dipilih berdasarkan 201 lokasi banjir, termasuk Topographic Wetness Index (TWI), kepadatan sungai, aliran indeks daya (SPI), kelengkungan, jarak dari sungai, litologi, ketinggian, kemiringan tanah, penggunaan lahan dan curah hujan. Algoritma yang dipakai adalah ANFIS with cultural (ANFIS-CA), bees (ANFIS-BA), dan invasive weed optimization (ANFIS-IWO). Hasil penelitian menunjukkan bahwa ANFIS-IWO dengan RMSE lebih rendah $(0,359)$ memiliki kinerja yang lebih baik, sementara ANFIS-BA dengan AUROC lebih tinggi $(94,4 \%)$ menunjukkan kemampuan prediksi yang lebih baik, diikuti oleh ANFIS-IWO $(93,9 \%)$ dan ANFIS-CA (92,1\%).

Moon et al (2019) mengkaji tentang peringatan dini hujan di Korea yang dapat mengeluarkan sinyal sebelum terjadinya hujan yang ekstrim dengan teknik pembelajaran mesin. Sinyal peringatan akan keluar jika kriteria hujan lebat yang ditetapkan tercapai, sehingga kejadian hujan lebat dalam 3 jam berikutnya dapat diprediksi. Hal tersebut dilakukan dengan cara melakukan diskretisasi variabel input secara selektif, menerapkan principal component analyses dan sebagai pengklasifikasi untuk memprediksi diperlukan atau tidaknya peringatan, digunakan regresi logistik.

Darabi et al (2019) melakukan penelitian tentang pemetaan risiko banjir perkotaan di Iran di Kota Sari melalui teknik pembelajaran mesin dengan menerapkan model Genetic Algorithm Rule-Set Production (GARP) dan model Quick Unbiased Efficient Statistical Tree (QUEST) serta membandingkan kedua aplikasi model tersebut. Untuk analisis bahaya banjir digunakan faktor curah hujan, kemiringan, jumlah kurva, jarak ke sungai, jarak ke saluran, kedalaman ke air tanah, penggunaan lahan dan ketinggian. Untuk analisis kerentanan banjir, digunakan faktor kepadatan kota, kualitas bangunan, usia bangunan, kepadatan penduduk dan kondisi sosial ekonomi. Selain itu, penentuan bobot faktor ditentukan berdasarkan pengetahuan para ahli dan Fuzzy Analytical Network Process (FANP). Hasil yang didapatkan menunjukkan bahwa model GARP mempunyai kinerja yang lebih baik dengan nilai receiver-operator characteristic curve (AUC$\mathrm{ROC})=93.5 \%$ dan $\mathrm{Kappa}=0.86$ dibandingkan dengan QUEST dengan nilai AUC-ROC = $89.2 \%$ dan Kappa $=0.79$. Selain itu hasil penelitiannya juga menunjukkan bahwa jarak ke saluran, penggunaan lahan, dan ketinggian memainkan peran utama dalam penentuan bahaya banjir, sedangkan kepadatan populasi, kualitas bangunan, dan kepadatan kota adalah faktor yang paling penting dalam hal 
kerentanan. Model ini dianggap sebagai metode cepat yang dapat memprediksi risiko banjir di perkotaan. Darabi et al. (2019) juga menyebutkan bahwa model pembelajaran mesin dapat membantu dalam pemetaan risiko banjir, terutama pada area di mana data hidrolika dan hidrologi yang terperinci tidak tersedia.

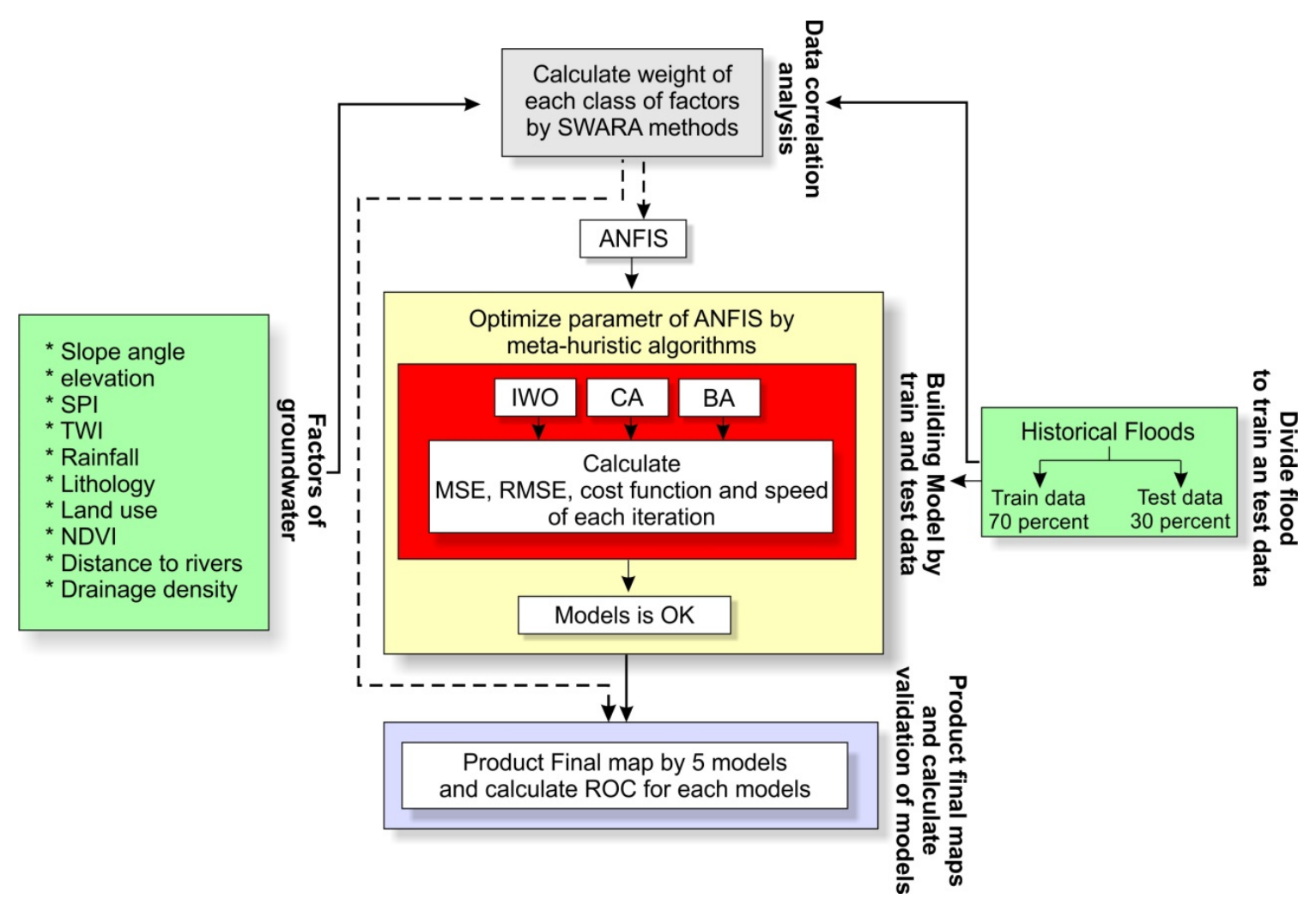

Gambar 5. Metodologi penelitian Bui et al (2018).

Prawiradisastra (2017) melakukan pengkajian kemungkinan penerapan ANFIS, ANN dan FIS untuk memprediksi tinggi muka air (TMA) pada Sungai Ciliwung. ANFIS dan ANN dipakai untuk membandingkan model mana yang memiliki performa paling baik untuk memprediksi tinggi muka air di pintu air Depok. Keluaran dari model yang paling baik akan dipakai sebagai masukan bagi model FIS untuk memprediksi tinggi muka air di pintu air Manggarai. RMSE dari hasil tes pada model ANN terbilang cukup tinggi. Rata-rata RMSE pada model ANN dengan 6, 24 dan 48 fitur adalah 52.5764, 35.6601 dan 70.7277 secara berurutan. Dapat disimpulkan bahwa model ANN tidak bisa diandalkan untuk memprediksi tinggi muka air di Depok. Model ANFIS memiliki performa yang lebih baik dibandingkan dengan model ANN dalam hal ini ANFIS dengan 3 fitur dipilih karena memiliki performa paling baik diantara seluruh model yang diuji cobakan. Rata-rata RMSE untuk ANFIS dengan 3 fitur adalah 18.2222. Oleh karena itu hasil prediksi dari model ini akan digunakan sebagai masukan untuk model FIS. Hasil RMSE (\%) dari model FIS cukup rendah yaitu rata-rata 3.43 yang artinya model FIS dapat memprediksi tinggi muka air di pintu air Manggarai dengan akurasi yang baik.

\subsubsection{Penerapan Kecerdasan Artifisial Pada Tahap Tanggap Darurat Bencana Banjir}

Robertson et al (2019), menggunakan data media sosial pada saat bencana untuk membantu tim penyelamat dalam menemukan korban. Penelitian Robertson et al (2019) ini membandingkan gambar korban yang dikirim selama Hurricane Harvey tahun 2017 ke dalam klasifikasi pembelajaran mendalam atau deep learning yang dipelajari dengan metode pembelajaran mesin. Kerangka kerja untuk ekstraksi fitur menggunakan VGG-16 convolutional neural network atau klasifikasi multilayer perceptron untuk mengklasifikasikan urgensi dan periode waktu untuk gambar yang diberikan (Gambar 6). 


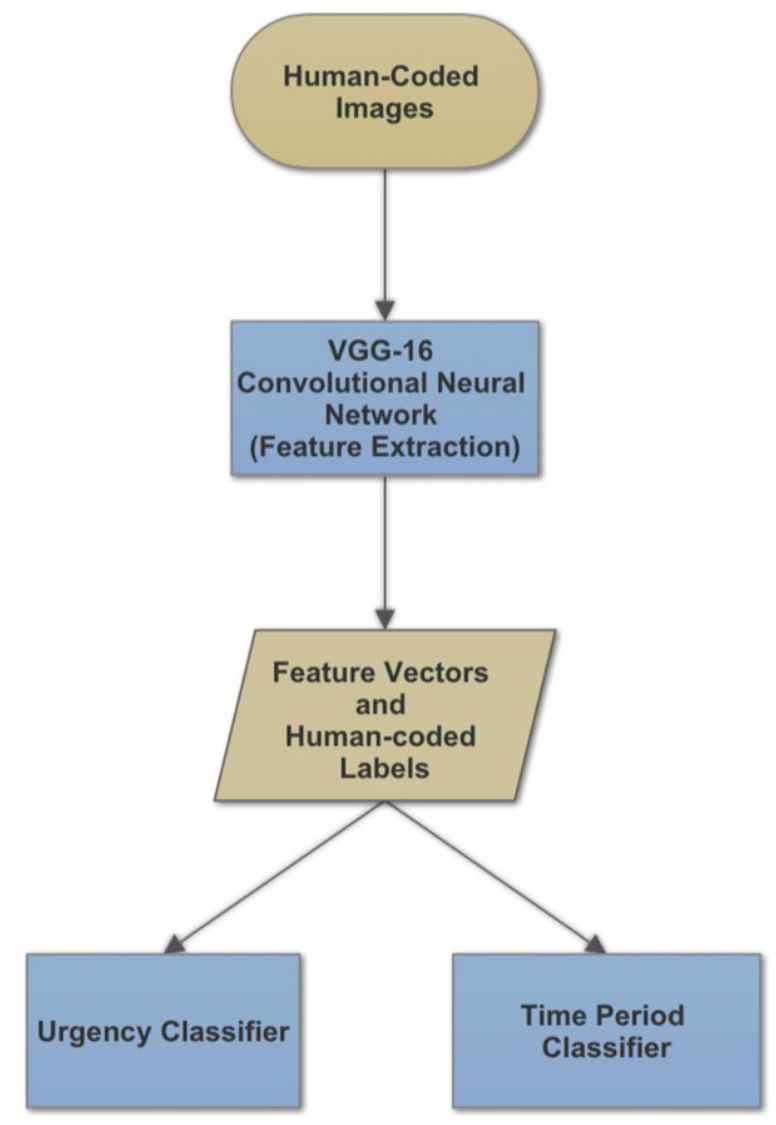

Gambar 6. Metode klasifikasi yang digunakan Robertson et al (2019).

Zahra et al (2020) telah melakukan penelitian tentang penggunaan Twitter pada saat kejadian bencana dengan bantuan pembelajaran mesin yang hasilnya dapat digunakan untuk keperluan tanggap darurat bencana. Pendekatan yang dilakukan, sukses untuk menggabungkan analisis crowdsource dan pembelajaran mesin, dan meningkatkan pemahaman dan kemampuan mengidentifikasi laporan saksi mata yang penting pada saat kejadian bencana.

\subsubsection{Penerapan Kecerdasan Artifisial Pada Tahap Pascabencana Banjir}

Arinta dan Emanual (2019) mengatakan bahwa penelitian penerapan kecerdasan artifisial pascabencana memang belum banyak dilakukan. Big data dan pembelajaran mesin di bidang ini memang masih sangat jarang. Karena untuk melakukan topik ini, ahli harus benar-benar memeriksa daerah bencana dan melakukan proses infrastruktur dari daerah yang rusak akibat bencana alam.

Penelitian mengenai penerapan kecerdasan artifisial untuk pascabencana dilakukan oleh Ghaffarian et al (2019) dimana penelitian tersebut mencoba menginformasikan kerusakan gedung untuk membantu proses rekonstruksi pascabencana, yang memang tidak spesifik pada bencana banjir. Ghaffarian et al (2019) menggunakan metode pembelajaran mendalam atau deep learning dan, khususnya, pendekatan konvolusional berbasis jaringan saraf atau Convolutional Neural Network untuk mengekstrak informasi dari citra satelit, khususnya untuk penilaian kerusakan bangunan (Gambar 7). Analisis eksperimental dilakukan pada citra satelit dengan resolusi sangat tinggi terpilih yang mewakili berbagai skenario setelah Topan Haiyan 2013 baik pada saat terjadi kerusakan dan pada fase pemulihan di Tacloban, Filipina. Hasilnya menunjukkan bahwa model ini cukup tangguh seperti yang diusulkan pada kerangka kerja ResUnet-CRF dalam memperbarui peta bangunan setelah bencana untuk kerusakan dan pemulihan dengan menghasilkan skor $F_{1}$ keseluruhan $84,2 \%$. 


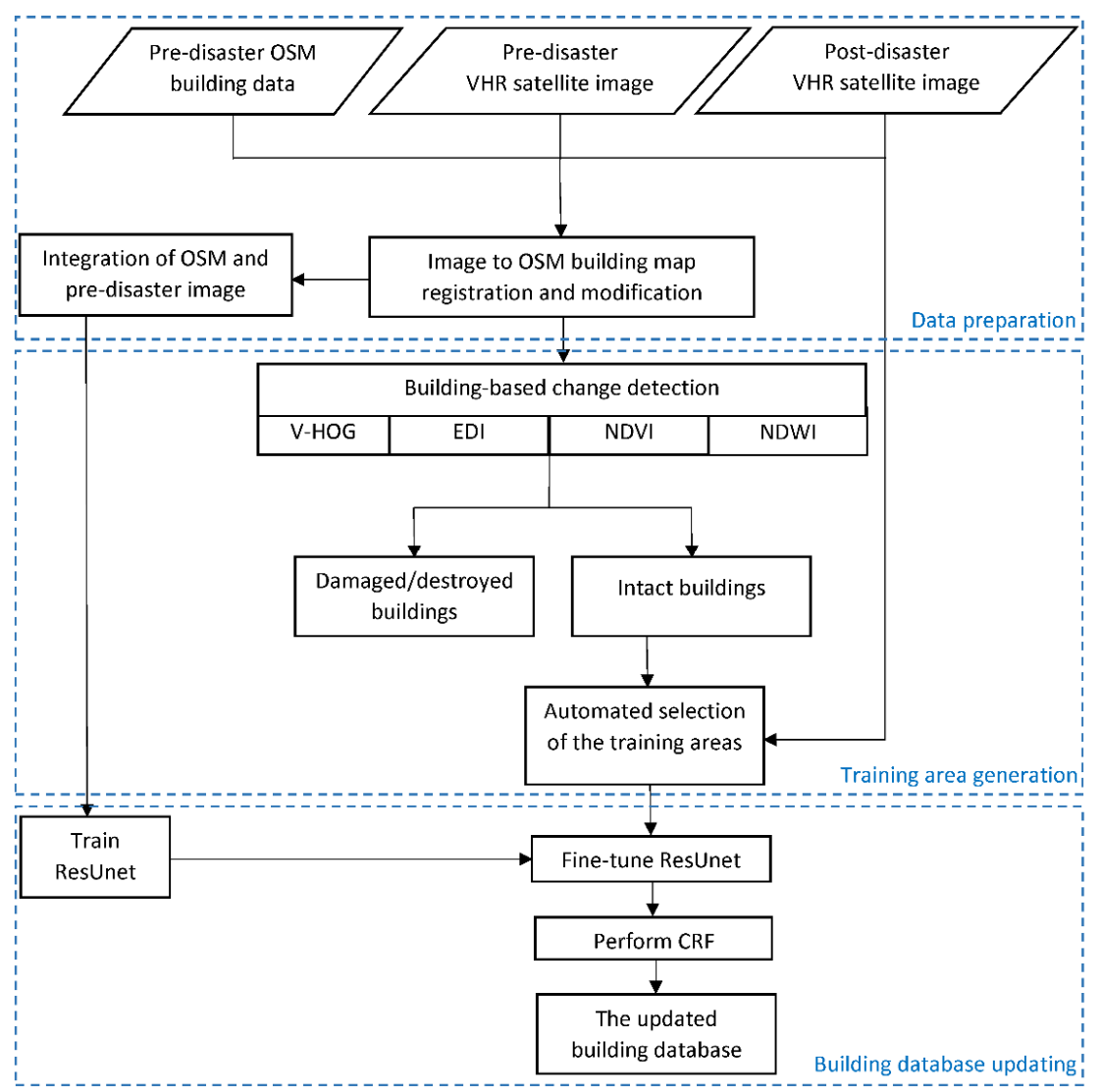

Gambar 7. Metode penelitian Ghaffarian et al (2019).

Shyekhmousa et al (2019), melakukan penelitian penerapan algoritma pembelajaran mesin dalam hal ini SVM untuk diimplementasikan pada fase pemulihan pascabencana Typhoon Haian di Tacloban, Filipina. Fase pemulihan pasca bencana ini bisa disamakan untuk berbagai jenis bencana termasuk banjir untuk perubahan penggunaan dan tutupan lahan pascabencana. Produk akhir dari penelitian ini adalah peta pemulihan berbasis penggunaan dan tutupan lahan yang mengukur proses pemulihan pascabencana di tingkat piksel. Ditemukan bahwa pemulihan fisik dan pemulihan fungsional dapat dijelaskan melalui informasi Land Cover and Land Use Change (LCLUC). Selain itu, peta pemulihan berbasis Land Cover (LC) dan Land Use (LU) mendukung pemahaman pemulihan secara umum dan terperinci.

\section{KESIMPULAN}

Data kejadian bencana banjir di Indonesia dalam dekade terakhir menunjukkan tren yang meningkat. Banjir adalah salah satu jenis bencana hidrometeorologi yang kejadiannya mendominasi setiap tahun di Indonesia dengan jumlah kejadian $>90 \%$. Upaya mitigasi bencana banjir memerlukan terobosan ilmu pengetahuan teknologi untuk mereduksi kerugian yang ditimbulkan akibat bencana tersebut.

Penerapan kecerdasan artifisial atau artificial intelligence dan pembelajaran mesin yang berkembang cepat dalam dekade terakhir menunjukkan bahwa metode ini terbukti mampu meningkatkan mitigasi bencana banjir. Berdasarkan hasil studi literatur didapatkan bahwa kecerdasan artifisial ini mampu dengan akurat dan cepat berperan dalam mitigasi banjir baik dalam tahap prabencana, saat tanggap darurat maupun pascabencana. Studi literatur menunjukkan bahwa metode ini mampu secara cepat dan akurat melakukan prediksi banjir, membuat pemetaan risiko banjir, berfungsi dalam masa tanggap darurat banjir maupun pemetaan kerusakan akibat banjir.

Metode pembelajaran mesin seperti ANNs, SVM, SVR, ANFIS, WNN dan DTs merupakan metoda populer yang digunakan pada saat prabencana dan direkomendasikan untuk menggunakan gabungan atau hibrid dari metode tersebut. Sementara untuk tahap tanggap darurat bencana beberapa penelitian menggunakan big data dari media sosial Twitter dan pembelajaran mesin baik supervised learning dengan Random Forest dan 
unsupervised learning dengan CNN menunjukkan hasil yang baik dan mempunyai prospek yang bagus untuk diterapkan walaupun masih harus dilakukan pengembangan. Sedangkan untuk fase pascabencana belum banyak penelitian tentang kecerdasan artifisial yang dilakukan pada saat ini, dikarenakan berbagai faktor diantaranya peneliti harus dengan baik mememeriksa kondisi di lapangan dan data yang tersedia belum banyak untuk fase ini sehingga masih harus dilakukan penelaahan lebih lanjut.

\section{DAFTAR PUSTAKA}

Arinta, R.R. dan E. Andi W.R. 2019. Natural Disaster Application on Big Data and Machine Learning: A Review. Proceeding. The $4^{\text {th }}$ International Conference on Information Technology, Information Systems and Electrical Engineering (ICITISEE) Yogyakarta, Indonesia. 249 254.

BNPB. 2020. Data Bencana Indonesia. Badan Nasional Penanggulangan Bencana [terhubung berkala]. https://bnpb.cloud/dibi/ [6 April 2020].

BPPT. 2018. Kongres Teknologi Nasional (KTN) 2018. Badan Pengkajian dan Penerapan Teknologi. [terhubung berkala]. http://ktn.bppt.go.id/ktn2018/ [20 April 2020].

Bui, D.T., K. Khosravi, S. Li, H. Shahabi, M. Panahi, V. P. Singh, K. Chapi, A. Shirzadi, S. Panahi, W. Chen dan B Bin Ahmad. 2018. New Hybrids of ANFIS with Several Optimization Alghorithms for Flood Susceptibility Modeling. Water. 10 (1210): 1-28.

Chang, L., M. Amin, S-N. Yang dan F-J Chang. 2018. Building ANN-Based Regional MultiStep-Ahead Inundation Forecast Model. Water. 10(1283): 1-18.

ESCAP. 2015. United Nations. Disasters in Asia and the Pacific: 2015 Year in Review. Available online. [terhubung berkala]. https://www.unescap.org/sites/default/files/ 2015_Year\%20in\%20Review_final_PDF_1 .pdf [15 April 2020].

Darabi, H., B. Choubin., O. Rahmati, A. T. Haghighi, B. Pradhan dan B. Kløve. 2019. Urban Flood Risk Mapping Using the GARP and QUEST Models: A Comparative Study of Machine Learning Techniques. Journal of Hydrology. 569: 142-154.

Fitriyaningsih, I., Y. Basani dan L.M. Ginting. 2018. Web-Based Application Development for Predicting Rainfall, Water
Discharge, and Flood Using Machine Learning Method in Deli Serdang, Jurnal Penelitian Komunikasi dan Opini Publik. 22 (2):132-143.

Fujitsu. 2019. Japan: Fujitsu develops Al disaster mitigation technology to predict river flooding with limited data. [terhubung berkala]. https://www.preventionweb.net/ news/ view/67241 [10 April 2020].

Ghaffarian, S., N. Kerle, E. Pasolli dan J.J. Arsanjani. 2019. Post-Disaster Building Database Updating Using Automated Deep Learning: An Integration of PreDisaster OpenStreetMap and MultiTemporal Satellite Data. Remote Sensing. 11 (2427): 1-20.

Kompas. 2018. Penanganan Bencana di Indonesia Masih Jadi Beban APBN. [terhubung berkala]. https://ekonomi. kompas.com/read/2018/10/10/154635126/ penanganan-bencana-di-indonesia-masihjadi-beban-apbn [12 April 2020].

Mosavi, A., P. Ozturk dan K. Chau. 2018. Flood Prediction Using Machine Learning Models: Literature Review. Water. 10 (1536): 1-40.

Prawiradisastra, F. 2017. Development of Flood Prediction Model Using Adaptive Neuro Fuzzy Inference System (ANFIS) for Ciliwung River. Thesis. IPB University.

Republik Indonesia. 2007. Undang Undang Republik Indonesia Nomor 24 Tahun 2007 tentang Penanggulangan Bencana. [terhubung berkala]. https: //bnpb.go.id/ppid/file/UU_24_2007.pdf [17 April 2020].

Robertson, B.W., M. Johnson, D. Murthy, W.R. Smith dan K. K. Stephens. 2019. Using a Combination of Human Insight and 'Deep Learning for Real-Time Disaster Communication. Progress in Disaster Science. 2: 1-11.

Sanubari, A.R. 2018. Pemodelan Prediksi Banjir Menggunakan Artificial Neural Network. Skripsi S1. Prodi Sistem Komputer. Fakultas Teknik Elektro. Universitas Telkom.

Moon, S-H., Y-H. Kim, Y.H. Lee, B-R. Moon. 2019. Application of Machine Learning to An Early Warning System for Very ShortTerm Heavy Rainfall. Journal of Hydrology 568: 1042-1054.

Shyekhmousa, M., N. Kerle, M. Kuffer dan S. Ghaffarian. 2019. Post-Disaster Recovery Assessment with Machine LearningDerived Land Cover and Land Use Information. Remote Sensing. 11 (10): 1174.

Soebroto, A.A., I. Cholissodin, R.C. Wihandika, 
M.T. Frestiyanti dan Z.E. Arif. 2015. Prediksi Tinggi Muka Air (TMA) untuk Deteksi Dini Bencana Banjir Menggunakan SVR-TVIWPSO. Jurnal Teknologi Informasi dan IImu Komputer. 2 (2): 79-86.

Wagenaar, D., A. Curran, M. Balbi, A. Bhardwaj, R. Soden, E. Hartato, G.M. Sarica, L. Ruangpan, G. Molinario dan D. Lallemant. 2020. Invited Perspectives: How Machine Learning Will Change Flood Risk and Impact Assessment. Natural Hazard Earth System Sciences. 20: 11491161.

Zahra, K., M. Imran dan F.O. Ostermann. 2020. Automatic Identification of Eyewitness Messages on Twitter During Disasters. Information Processing and Management. 57(102107). 